\title{
IMPACT OF DIGITAL MEDIA ON STUDENTS' ENGAGEMENT VIA E-LEARNING: A CRITICAL LITERATURE REVIEW USING BIBLIOGRAPHIC ANALYSIS
}

\author{
Dr. Disha Sharma \\ Assistant Professor \\ Amity Business School, Amity University Chhattisgarh, Raipur \\ Prof. Shilpi Gupta \\ Assistant Professor \\ Amity Business School, Amity University Chhattisgarh, Raipur
}

\begin{abstract}
The conventional learning style and engagement of students has changed since the inception of digital media. The present paper purpose is to delve into the literature of the last decade and to track the progression of digital media in context to student's engagement in e-learning through critically accessing the literature. The study was conducted with 300 published articles based on the selected keyword 'Digital Media', 'Students Engagement', and 'E-Learning' in the last 10 years. Researchers systematically analyzed the articles, following type and period of publication; publisher wise; citations, publishers, and years; authors; titles; and top journals to identify the impact of Digital Media. The finding provides the role of Digital media and its impact on E-Learning patterns of students. Furthermore, it is accommodating in comprehending the students in putting the knowledge gained through Digital Media to optimal use. Based on finding this platform can be enlarged to serve all streams of learning materials. Confiding Digital Media only for Learning of Students could be considered a narrow approach, hence part from selected keyword studies could also be conducted. The present research will help future researchers and academician to have a clear understanding of Digital Media to utilize it as learning.
\end{abstract}

Keyword: Digital Media; E-Learning; Students Engagement; Communication; Internet; Bibliometric.

\section{INTRODUCTION}

The spread of the Internet has led towards providing an opportunity to digital media. Since its inception digital media is becoming huge, everything is being united. By providing multiple channels, to communicate across, one-way communication digital media has made it a two-way communication (Fitzgerald, Kruschwitz, Bonnet, \& Welch, 2013; Johri, Teo, Lo, Dufour, \& Schram, 2014; Kalorth \& Verma, 2018; Lupton, 2017; Narula \& Shiva, 2020; Van Leer \& Connor, 2012). For any business digital media is of getting the right message to the right person at the right time with the right media (Bimber, 2017; Gershon, 2013). Digital media is providing a platform to reproduce, put the matter out there, and made a difference (Abou-Khalil et al., 2021). Digital media is about the power and the ability to tell the story, in a way that it can interact and contribute to the whole world (Boulianne, 2020; Verma, 2015). Digital media is not only doing it but it is doing it cheaply and anyone can do it if they want to (Kalorth, Verma, \&
Sagar, 2020; Lupton, 2017). Tonini, Albizzati, \& Astrup, (2018), has said that through digital media you tell a story to a customer while maintaining consistency, you must engage them, and you must repeat the message repeatedly.

Verma, (2015) considered the internet as one of the prime things to reiterated and the digital media have provided public relation with a new facilitator to gather information and keeping an eye on the public concerning issues. Digitalization of the media has an association with all the parallel factor to the world of web, concerning the learnings of the students, engagements of the users, and its impact on daily life (Chen, Lambert, \& Guidry, 2010; Huang-Saad, Gibson, Goebel, Sheridan, \& McNaughton, 2016; Narula, 2016; Siregar, 2021; Tran et al., 2020). Initially, learning through media seems to read some dystopian novel and bizarre at some point, but through the use of technology, they are searching for the remedy (Dawadi, Giri, \& Simkhada, 2020; 
Taylor \& Parsons, 2011). Traditionally, many critiques believe that traditional lectures provide the optimal form of learning and it turns out that this is an online learning argument aside from just a blatantly wrong statement (Kaur, Bir, Chandran, \& Deepak, 2021; Verma, 2015). In 1984, Bloom did experiment on various types of teachinglearning system and saw that traditional classroom setting was the least effective ways of disseminating knowledge to the students, he added it with a quote;

\section{"It makes no sense to expect all students to take the same amount of time to achieve the same} objectives."

Benjamin S. Bloom

On the other hand, Strasser (2011), believes that digital learning has exposed students to a wide Sources of superficial information but ignoring the core pieces of learning that the students encounter during learning breakdowns. Boutzoukas, Akinboyo, Wong, Benjamin, \& Zimmerman, (2021), have concluded in their paper that digital learning has a long-lasting impact on the significant intelligence of the learners, García-Peñalvo, Figuerola, \& Merlo, (2008), have clearly expressed their concern about the ensured and equitable access to the educational services. Students Engagement with Digital learning and its understanding to sustain the involvement towards the learning content could give a different approach to study these variables (Abou-Khalil et al., 2021). Thus, the mixed responses on Digital Media and ELearning have introduced the parameter of Students Engagement (Song, Singleton, Hill, \& Koh, 2004), Also, during recent developments, the impact of digital media over the engagement of students through E-Learning has expanded immensely (Khan, Vivek, Nabi, Khojah, \& Tahir, 2021).

In the present research paper, three variables were considered all the three variables i.e., Digital Media, E-Learning and Students Engagement variedly, and used in the bibliometric analysis to comprehend the published literature. To develop the generalized framework, the Impact of Digital Media on the Students Learning through the E-Learning. In this study, the four databases are used to summarize the publication on the considered variables.
The paper is divided into four parts: the first part represents the methodology applied in the study: the second part represents the result of the literature review considered; the third part focusses on the application of Sankey and word cloud, and the fourth part consists of conclusion and direction for future research.

\section{RESEARCH METHODOLOGY Data Extraction:}

An ample amount of research has been done on Digital Media, E-Learning and Students Engagement. The review has been done systematically. In this research paper the following database are searched:

- Scopus.

- Web of Science.

- Taylor and Francis.

- Elsevier's Science Direct.

The number of related papers on databases were countless and not possible to read. Hence, the period set for the selection of the published paper is from 2011-2020. Only those papers were targeted which had the keyword of Digital Media, E-Learning and Students Engagement are considered for the study. To access and evaluate the information the authors used basic computation tools following by a third-party tool for the Sankey and Word cloud. The incorporation of Sankey will lead to better visualization of the factors used which depicts the Journal-Year wise flow with Citations. This will help the readers to establish the growth/decline in the publishing of a particular keyword. The word-cloud figures will explain the frequency of repetition of the keyword throughout the last 10 years, this explains the dominancy of each keyword all over the period considered. After the selection of the documents, the paper was distributed based on the keyword selected for the present study.

\section{RESULTS}

Based on the above-mentioned criteria and available database a total of 300 articles were selected for the study. Based on the keyword selected that is Digital Media, E-Learning and Students Engagement 100 articles selected from each. The paper selected were analyzed on the following parameters:

- type and period of publication.

- publisher wise. 
- citations, publishers, and years.

- authors.

- titles.

- top journals

Distribution of articles based on types and period of publication

The study of this paper is divided into the various period and the type of paper. The period of 10 years is divided into five different phases:

Table 1 Distribution of articles based on phases

\begin{tabular}{|l|c|c|c|c|}
\hline \multicolumn{2}{|c|}{ Year/ Keyword } & $\begin{array}{c}\text { Digital } \\
\text { Media }\end{array}$ & $\begin{array}{c}\text { Students } \\
\text { Engagement }\end{array}$ & $\begin{array}{c}\text { E- } \\
\text { Learning }\end{array}$ \\
\hline Phase 1 & $\begin{array}{c}2011- \\
2012\end{array}$ & 37 & 28 & 19 \\
\hline Phase 2 & $\begin{array}{c}2013- \\
2014\end{array}$ & 23 & 20 & 15 \\
\hline Phase 3 & $\begin{array}{c}2015- \\
2016\end{array}$ & 22 & 21 & 22 \\
\hline Phase 4 & $\begin{array}{c}2017- \\
2018\end{array}$ & 14 & 17 & 23 \\
\hline Phase 5 & $\begin{array}{c}2019- \\
2020\end{array}$ & 4 & 14 & 21 \\
\hline
\end{tabular}

Source: Author's Calculation

Based on the above study, it is apparent that enormous research was conducted in keyword 'Digital Media' but gradually it starts declining steeply in the subsequent years. However, in the case of the keyword 'Student's Engagement,' the research pattern is in a declining phase but in the case of the keyword 'E-Learning,' it is rather growing (Figure 1). Along with that, it is also clear that more than 85 per cent of research is based on empirical analysis, which is almost constant from the last decade (Figure 2).

Figure 1: Distribution of data based on period of publication

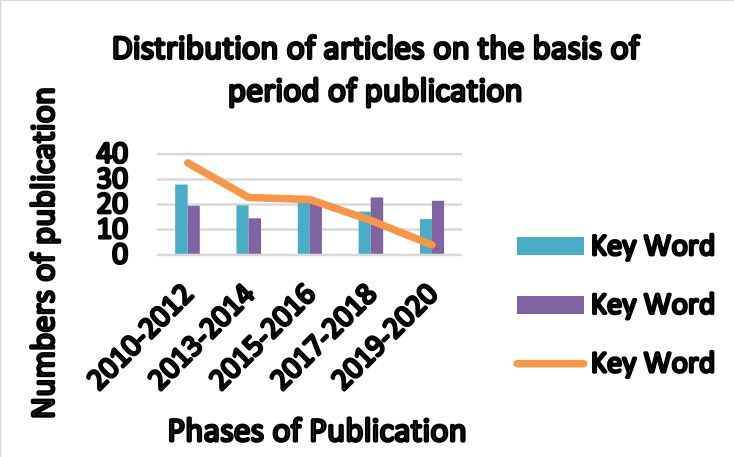

Source: Author's Calculation
Figure 2: Distribution of data based on types of paper

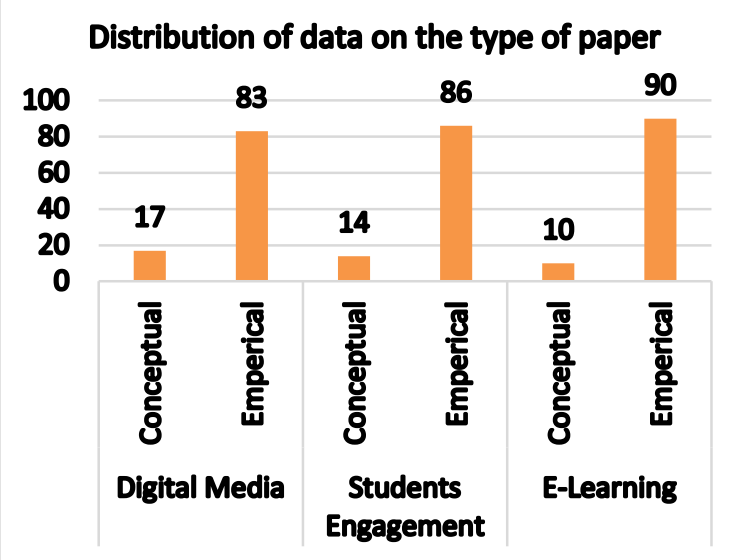

Source: Author's Calculation

Distribution of articles in terms of publishers Publisher wise distribution of the articles is shown in Table 2. This table shows that out of 300 articles considered for the present study, we can identify only 16 publishers. Out of 16 , only 6 publishers have published more than 25 research articles. These are namely, Elsevier (66 articles), Sage Publication (44 articles), JSTOR (25 articles), Springer (35 articles), Taylor \& Francis (73 articles) \& Wiley Online Library (27 articles). All these publishers published 90 per cent of the research articles considered for the present study.

Table 2: Distribution of articles publisher wise

\begin{tabular}{|l|c|}
\hline Publishers & $\begin{array}{c}\text { Number of } \\
\text { articles }\end{array}$ \\
\hline Oxford Academic Journal & 5 \\
\hline $\begin{array}{l}\text { American Academy of } \\
\text { Paediatrics }\end{array}$ & 1 \\
\hline Cambridge University Press & 2 \\
\hline De Gruyter & 1 \\
\hline Educational Technology Journal & 1 \\
\hline Elsevier & 66 \\
\hline Emerald & 3 \\
\hline ERIC & 4 \\
\hline IEEE Xplore & 5 \\
\hline University of South California & 1 \\
\hline Inderscience Online Publishers & 7 \\
\hline Sage Publication & 44 \\
\hline JSTOR & 25 \\
\hline Springer & 35 \\
\hline Taylor \& Francis & 73 \\
\hline Wiley Online Library & 27 \\
\hline Total & 300 \\
\hline Source: Author's Calation
\end{tabular}

Source: Author's Calculation 
Distribution of articles based on citations, publishers, and years.

The analysis based on Citation, publishers, and year-wise distribution for keyword 'digital media' is shown in Figure 3, for the keyword 'student's engagement' in Figure 4, and for the keyword, 'E-Learning' is in Figure 5. The width of the arrows in the Sankey diagram represents the size of the respective publishers and the years published. The Sankey diagram of the citations for the publishers followed by the years published. Since the Sankey diagram for the keyword 'digital media' and 'E-Learning' looks like each other in terms of the years published, regarding the proportions to the arrow to another. The publishing weightage for both the keywords is more on 'Taylor and Francis' and 'Elsevier' respectively, that too in the initials years of the considered period. However, in the case of the keyword 'student's engagement', the width of the arrows is uniform and almost equally distributed, which makes the distributions even in the case of publishers as well as in the years.

Figure 3: Distribution of digital media articles based on publishers, years, and citations

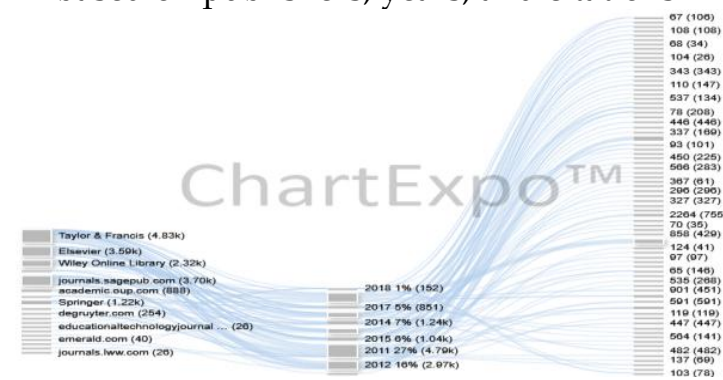

Source: Author's Calculation

Figure 4: Distribution of Student's engagement articles based on publishers, years, and citations

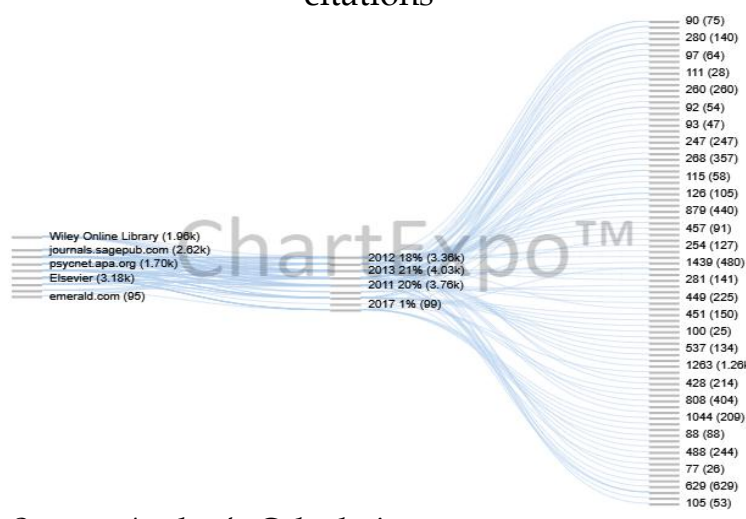

Source: Author's Calculation
Figure 5: Distribution of E-Learning articles based on publishers, years, and citations

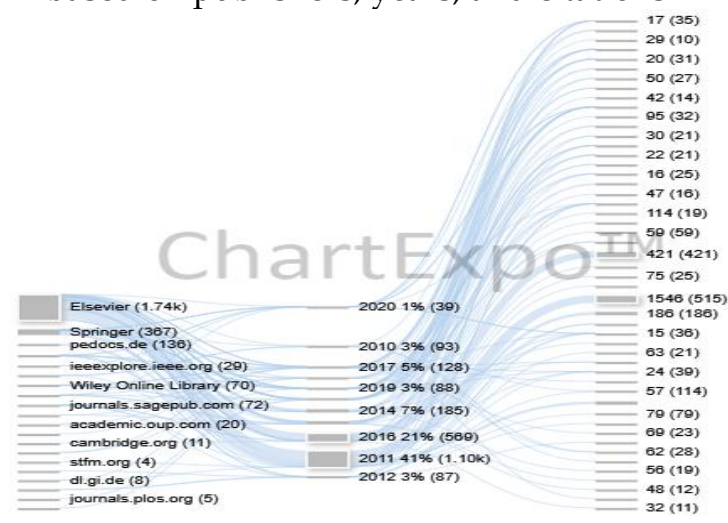

Source: Author's Calculation

Distribution of articles based on authors

Amongst all the 300 papers considered for the present study. The list of authors who have published at least 2 number of paper publications, is presented in Table 3, with a total of 10 such authors. However, J Reeve is at the top of the list with 4 papers published on the keyword 'student's engagement', remaining 9 authors are at the same number of 2 paper publications.

Table 3: Author-wise distribution of the articles

\begin{tabular}{|c|c|c|}
\hline Keyword & Authors & $\begin{array}{c}\text { Number of } \\
\text { Published } \\
\text { Papers }\end{array}$ \\
\hline $\begin{array}{c}\text { Students } \\
\text { Engagement }\end{array}$ & J Reeve & 4 \\
\hline $\begin{array}{c}\text { Students } \\
\text { Engagement }\end{array}$ & D Alt & 2 \\
\hline $\begin{array}{l}\text { Digital } \\
\text { Media }\end{array}$ & D Lupton & 2 \\
\hline $\begin{array}{c}\text { Students } \\
\text { Engagement }\end{array}$ & E Huhtamo & 2 \\
\hline $\begin{array}{l}\text { Digital } \\
\text { Media }\end{array}$ & ER Kahu & 2 \\
\hline $\begin{array}{c}\text { Students } \\
\text { Engagement }\end{array}$ & JT Guthrie & 2 \\
\hline $\begin{array}{c}\text { Students } \\
\text { Engagement }\end{array}$ & MT Wang & 2 \\
\hline $\begin{array}{c}\text { Students } \\
\text { Engagement }\end{array}$ & R Junco & 2 \\
\hline $\begin{array}{c}\text { Digital } \\
\text { Media \& E- } \\
\text { Learning } \\
\end{array}$ & S Quinton & 2 \\
\hline $\begin{array}{l}\text { Digital } \\
\text { Media }\end{array}$ & $\begin{array}{l}\text { WL Bennett, } \\
\text { A Segerberg }\end{array}$ & 2 \\
\hline
\end{tabular}

Source: Author's Calculation 
Distribution of articles based on titles

During the studies of the keyword and selection of a total of 300 papers, we considered the title of each research paper is being considered for the frequency evaluation through a word cloud. For the word cloud (Figure 6) a total of 350 words from the titles of each keyword was taken into consideration for the word cloud. From the study, it is evident that the author's study revolves around the keywords selected by us along with those authors also paid attention towards social, political, literacy, development etc.

Figure 6: Distribution of article's title based on keywords

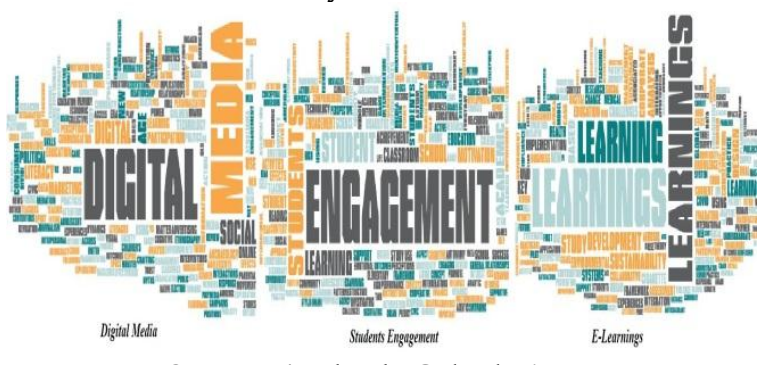

Source: Author's Calculation

It has been inferred from the combined word cloud that; Digital media is the dominating variable considered by an author. Further social, literacy, age, technology, community, classrooms, students, marketing, learning are the others dominating variable taken for the Digital Media studies.

Figure 7: Distribution of titles based on all the keywords combined

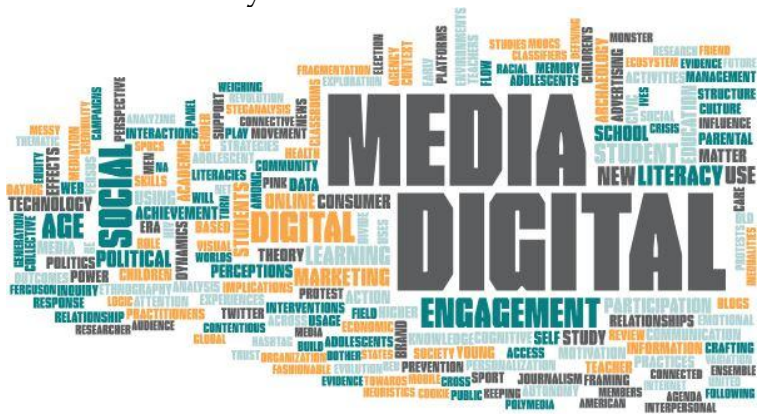

Source: Author's Calculation

\section{Distribution of articles based on Journals}

Journal wise distribution of articles is shown in Table 4. The results of the table reveal that there are very few journals specifically related to the keywords selected for the present study. Out of 300 articles considered for the study are published in 246 journals, three journals have published four or more than four articles.
These journals are namely Computers \& Education (7 articles), Journal of cleaner production (7 articles), Computers in Human Behavior (5 articles), Educational psychologist (4 articles), Information, Communication \& Society (4 articles), and Sustainability (4 articles). Twelve research journals have published more than three research articles.

Table 4: Journal wise distribution of the articles

\begin{tabular}{|l|c|}
\hline Name of the Journals & $\begin{array}{c}\text { Number of } \\
\text { Published } \\
\text { Papers }\end{array}$ \\
\hline Computers \& Education & 7 \\
\hline $\begin{array}{l}\text { Journal of cleaner } \\
\text { production Human }\end{array}$ & 7 \\
\hline $\begin{array}{l}\text { Computers in Hehavior } \\
\text { Berational psychologist }\end{array}$ & 4 \\
\hline Educationation, & 4 \\
\hline $\begin{array}{l}\text { Information } \\
\text { Communication \& Society }\end{array}$ & 4 \\
\hline Sustainability \\
\hline $\begin{array}{l}\text { Active learning in higher } \\
\text { education }\end{array}$ & 3 \\
\hline Business horizons & 3 \\
\hline $\begin{array}{l}\text { Contemporary Educational } \\
\text { Psychology }\end{array}$ & 3 \\
\hline $\begin{array}{l}\text { Handbook of research on } \\
\text { student engagement }\end{array}$ & 3 \\
\hline $\begin{array}{l}\text { Journal of educational } \\
\text { psychology }\end{array}$ & 3 \\
\hline Learning and Instruction & 3 \\
\hline Media Archaeology & 3 \\
\hline Paediatrics & \\
\hline Public relations review & \\
\hline Source:Aurs Caculton & \\
\hline
\end{tabular}

Source: Author's Calculation

\section{CONCLUSION}

The authors reviewed 300 research articles available in four renowned databases from 2011 to 2020. The result is divided into 6 subdivisions i.e. type and period of publication; publisher wise; citations, publishers, and years; authors; titles; and top journals, to identify them different methodologies are used. The observations of Table 1 depicted that distribution of articles based on the year of publication covered majorly the theme of Digital Media for the first half of the tenure considered and afterwards declined steeply; which represents the inclination of the researchers over novel themes, the focus needs to be on the remaining keywords along with digital media in a 
constant. Along with it, the authors are leaning more towards empirical papers. The need of undertaking the key aspects of study results into planning and implementation is required which can be done through conceptual work. The Sankey diagram shows that the major papers are published by the established publishers in the initial years with the highest citations. The need for acceptance and novelty is required by the researchers and the publishers so that more readers can be benefitted and could lead to more dissemination of knowledge.

Besides, the word cloud analysis results have showcased that digital media had a crucial role to play in students' engagement through e-learning. The involvement of digital media has positively impacted and the usage of the internet could be made more effective. Present research analyses the Digital Media in a decade and it is useful to utilise this platforms for E-Learning and to engage the youth that is students through it in a better and rational way. Besides, the word cloud analysis results have revealed that digital media has a crucial role to play in students' engagement through channelized e-learning. Further, future research can validate the factors considered with different other variables and in a large audience with focused groups. The present situation of the pandemic demands a higher focus on E-learning with the help of digital media and engaging the students towards a better and directed wisdom. The role of digital media can never be demeaned. The cooperation of digital media with E-learning in tune with student engagement is the need of the hour and can work towards the development of the nation towards prosperity and growth.

The literature review indicated the complexity of student's engagement and digital media. The presence of meaningful and relevant learning community support is the basic foundation of the correlation between digital media, students learning and student's engagement strengthening the student's social learning relations. Student engagement is much more than a behavioural aspect. The literature review conducted indicated that the students of the $21^{\text {st }}$ century are digital natives. The digital media builds up a plethora of accessible educational materials changing the perspective of learning from face to face in- person learning to a complex but fruitful technology of online chat, web discussion, question and answer on board and engaging the students in the benefits of e-learning. The rare but the most important ingredients of digital media, e-learning and students engagement in the right proportion will impact the whole economy of India in a positive and build a sustainable education system.

\section{REFERENCES}

Abou-Khalil, V., Helou, S., Khalifé, E., Chen, M. A., Majumdar, R., \& Ogata, H. (2021). Emergency online learning in lowresource settings: Effective student engagement strategies. Education Sciences, 11(1), 1-18. https://doi.org/10.3390/ educsci11010024

Bimber, B. (2017). Three Prompts for Collective Action in the Context of Digital Media. Political Communication, 34(1), 6-20. https://doi.org/10.1080/10584609.2016.1 223772

Bloom, B. S. (1987). A Response to Slavin's Mastery Learning Reconsidered. Review of Educational Research, 57(4), 507-508. https://doi.org/10.3102/00346543057004 507

Boulianne, S. (2020). Twenty Years of Digital Media Effects on Civic and Political Participation. Communication Research, 47(7), 947-966. https://doi.org/10.1177/ 0093650218808186

Boutzoukas, A. E., Akinboyo, I. C., Wong, C. A., Benjamin, D. K., \& Zimmerman, K. O. (2021). Impact of COVID-19-related School Closures on the Drivers of Child Health. North Carolina Medical Journal, 82(1), 50-56. https://doi.org/10.18043/ ncm.82.1.50

Chen, P. S. D., Lambert, A. D., \& Guidry, K. R. (2010). Engaging online learners: The impact of Web-based learning technology on college student engagement. Computers and Education, 54(4), 1222-1232. https://doi.org/ 10.1016/j.compedu.2009.11.008

Dawadi, S., Giri, R., \& Simkhada, P. (2020). Impact of COVID-19 on the Education Sector in Nepal - Challenges and Coping Strategies (Vol. 3). https://doi.org/ 10.31124/advance.12344336 
Fitzgerald, M., Kruschwitz, N., Bonnet, D., \& Welch, M. (2013). Embracing Digital Technology: A New Strategic Imperative | Capgemini Consulting Worldwide. MIT Sloan Management Review, 55(1), 113. Retrieved from https://www. capgemini-consulting.com/SMR

García-Peñalvo, F. J., Figuerola, C. G. de, \& Merlo, J. A. (2008). Open Knowledge Management in Higher Education.

Gershon, R. A. (2013). Digital media innovation and the apple IPAD: Three perspectives on the future of computer tablets and news delivery. Journal of Media Business Studies, 10(1), 41-61. https://doi.org/10.1080/16522354.2013.1 1073559

Huang-Saad, A., Gibson, M., Goebel, J., Sheridan, R., \& McNaughton, B. (2016). Student Learning Outcomes From a Multidisciplinary Capstone Entrepreneurship Course. Journal of Engineering Entrepreneurship, 7(1), 13-23. https://doi.org/10.7814/jeenvp

Johri, A., Teo, H. J., Lo, J., Dufour, M., \& Schram, A. (2014). Millennial engineers: Digital media and information ecology of engineering students. Computers in Human Behavior, $33(33$ (2014)), 286-301. https://doi.org/10.1016/j.chb.2013.01.04 8

Kalorth, N., \& Verma, M. (2018). Anatomy of fake news: On (mis)information and belief in the age of social media. Journal of Content, Community and Communication, 4(8), 9-14. https://doi.org/10.31620/ JCCC.12.18/03

Kalorth, N., Verma, M., \& Sagar, M. (2020). Information and User: Social Media Literacy in Digital Societies. Journal of Content, Community and Communication, 12, 263-269. https://doi.org/10.31620/ JCCC.12.20/24

Kaur, S., Bir, M., Chandran, D. S., \& Deepak, K. K. (2021). Adaptive strategies to conduct participant-centric structured virtual group discussions for postgraduate students in the wake of the COVID-19 pandemic. Advances in Physiology Education, 45(1), 37-43. https://doi.org/10.1152/advan.00136.20 20
Khan, M. A., Vivek, Nabi, M. K., Khojah, M., \& Tahir, M. (2021). Students' perception towards e-learning during the covid-19 pandemic in India: An empirical study. Sustainability (Switzerland), 13(1), 1-14. https://doi.org/10.3390/su13010057

Lupton, D. (2017). Digital media and body weight, shape, and size: An introduction and review. Fat Studies, 6(2), 119-134. https://doi.org/10.1080/21604851.2017.1 243392

Narula, S. (2016). Role of Youth in Peace Building via New Media: A Study on Use of New Media by Youth for Peace Building Tasks. Journal of Mass Communication $\mathcal{E}$ Journalism, 6(5). https:/ / doi.org/10.4172/21657912.1000311

Narula, S., \& Shiva, A. (2020). Editorial Pandemic and Role of Media. Journal of Content, Community and Communication, 12, 1-3. https://doi.org/10.31620/JCCC. $12.20 / 01$

Siregar, F. A. (2021). the Impact of the Covid-19 Pandemic on the Effectiveness of Learning Mathematics for Senior High School Students.

Song, L., Singleton, E. S., Hill, J. R., \& Koh, M. H. (2004). Improving online learning: Student perceptions of useful and challenging characteristics. Internet and Higher Education, 7(1), 59-70. https://doi.org/10.1016/j.iheduc.2003.11 .003

Strasser, T. (2011). Moodle im Fremdsprachenunterricht-Blended Learning.

Taylor, L., \& Parsons, J. (2011). Improving student engagement. Current Issues in Education, 14(1), 1-33.

Tonini, D., Albizzati, P. F., \& Astrup, T. F. (2018). Environmental impacts of food waste: Learnings and challenges from a case study on the UK. Waste Management, 76, 744-766. https://doi.org/10.1016/ j.wasman.2018.03.032

Tran, T., Hoang, A. D., Nguyen, Y. C., Nguyen, L. C., Ta, N. T., Pham, Q. H., ... Nguyen, T. T. (2020). Toward sustainable learning during school suspension: Socioeconomic, occupational aspirations, and learning behavior of vietnamese 
students during COVID-19. Sustainability (Switzerland), 12(10), 1-19. https://doi. org/10.3390/su12104195

Van Leer, E., \& Connor, N. P. (2012). Use of portable digital media players increases patient motivation and practice in voice therapy. Journal of Voice, 26(4), 447-453. https://doi.org/10.1016/j.jvoice.2011.05. 006

Verma, M. (2015). Public relations: Scope and challenges in digital era. Media Watch, 6(1), 148-152. https://doi.org/10.15655/ $\mathrm{mw} / 2015 / \mathrm{v} 6 \mathrm{i1} / 55399$ 